\title{
PENINGKATAN HASIL DAN NILAI NUTRISI RUMPUT KUMPAI (Hymenachne amplexicaulis (Rudge) Nees.) DENGAN FUNGI MIKORIZA ARBUSKULA DAN PUPUK ORGANIK DI TANAH PODZOLIK MERAH KUNING
}

\author{
Hardi Syafria 1), Novirman Jamarun 2), Mardiati Zein ${ }^{2)}$ dan Evita Yani ${ }^{2)}$ \\ 1)Fakultas Peternakan Universitas Jambi \\ 2) Fakultas Peternakan Universitas Andalas
}

\begin{abstract}
ABSTRAK
Fungi mikoriza arbuskula (FMA) dapat membantu tanaman untuk penyediaan dan penyerapan unsur P yang rendah ketersediaannya pada tanah masam. Pupuk organik dapat memberikan pengaruh terhadap sifat fisik, kimia dan biologis tanah. Tujuan penelitian ini adalah untuk mempelajari dan mengetahui pengaruh FMA dan pupuk organik terhadap peningkatan hasil dan nilai nutrisi rumput kumpai di tanah masam podzolik merah kuning. Penelitian menggunakan rancangan acak lengkap pola faktorial $5 \times 3$ dan ulangan tiga kali. Dua faktor sebagai perlakuan yaitu FMA dan pupuk organik. FMA terdiri dari tiga taraf: o g/pot, $10 \mathrm{~g} /$ pot dan $20 \mathrm{~g} /$ pot. Pupuk organik terdiri dari lima taraf: 0\%, 50\% pupuk kandang sapi, 100\% pupuk kandangsapi, 50\% pupuk kompos dan $100 \%$ pupuk kompos. Peubah yang diamati adalah panjang daun, lebar daun, panjang tanaman, jumlah anakan, jumlah daun, produksi bahan kering hijauan, berat kering akar, protein kasar, kandungan fosfor, kecernaan bahan kering dan kecernaan bahan organik in-vitro. Hasil penelitian menunjukkan bahwa pemberian FMA dan pupuk organik berpengaruh sangat nyata $(\mathrm{P}<0.01)$ terhadap semua peubah yang diamati. Sedangkan interaksi FMA dan pupuk organik berpengaruh sangat nyata terhadap berat kering akar, protein kasar, kandungan fosfor dan kecernaan bahan organik.
\end{abstract}

Kata kunci: Hymenache amplexicaulis (Rudge) Nees., fungi mikoriza arbuskula, pupuk organik, hasil dan nilai nutrisi.

\section{PENDAHULUAN}

Memperluas penganekaragaman hijauan pakan, maka hijauan lokal perlu dikembangkan guna menunjang kebutuhan hijauan untuk ternak ruminansia yang berbasis pada sumber daya lokal. Beberapa jenis hijauan lokal menunjukkan kelebihan atau keuntungan dibanding rumput introduksi. Salah satunya adalah rumput kumpai (Hymenachne amplexicaulis (Rudge) Ness). Rumput ini merupakan kekayaan sumber daya alam yang memiliki nilai biologis tinggi, serta turut menunjang ketersediaan hijauan pakan yang berkualitas. Kandungan protein kasarnya $( \pm 12,20$ $\%)$, lebih tinggi dibandingkan protein kasar rumput gajah (9-10 \%). Syafria (2009) menyatakan bahwa produksi bahan kering hijauan serta kandungan protein kasar rumput kumpai yang tertinggi diperoleh pada perlakuan tanpa penggenangan, pemupukan 300 $\mathrm{kg} \mathrm{N} /$ ha dengan interval pemotongan 40 hari. Syafria (2010) juga menemukan bahwa produksi bahan kering hijauan dan kandungan protein kasar rumput kumpai tertinggi diperoleh pada pemupukan $300 \mathrm{~kg} \mathrm{~N} / \mathrm{ha}$ dengan interval pemotongan 40 hari.

Lahan untuk penanaman hijauan semakin lama semakin berkurang, hal ini disebabkan antara lain karena lahan yang subur banyak dimanfaatkan untuk menanam tanaman pangan, perkebunan serta berbagai keperluan non pertanian. Salah satu usaha untuk memenuhi hijauan pakan bagi ternak adalah melalui pemanfaatan lahan marginal yang masih cukup luas di
Indonesia (Sumarsono, 2006; Anny Mulyani dan Irsal Lubis, 2008; Evitayani et al., 2012; Jamarun dan Zein, 2012). Luas tanah marginal podzolik merah kuning di Indonesia berkisar \pm 51 juta hektar, tersebar di Kalimantan, Sumatera, Sulawesi, Irian Jaya dan Jawa (Rachim et al., 2000). Di Jambi luasnya \pm 2.272 .725$ ha $(44,56$ \%) dari luasan Provinsi Jambi (Dinas Pertanian Tanaman Pangan Jambi, 2005). pH tanah masam, ketersediaan unsur hara serta kandungan bahan organiknya rendah, peka terhadap erosi, dan mempunyai kemampuan menahan air yang rendah (Mengel dan Kirkby, 2001). Sebagai media tumbuh tanaman ini akan mengalami kekurangan unsur hara esensial tertentu baik makro maupun mikro, dalam pemanfaatannya diperlukan upaya untuk memperbaiki produktivitasnya (Zuhry dan Puspita, 2008; Mulyani dan Las, 2008). Pemakaian bahan kimia dalam jumlah yang cukup banyak meskipun dapat meningkatkan pertumbuhan tanaman, namun sistem produksinya membutuhkan masukan dengan biaya tinggi dan dalam jangka panjang juga akan berdampak negatif terhadap lingkungan (Sukarmin dan Fatria, 2011). Menurut Husin et al. (2012) ketersediaan fosfat pada tanah masam juga menjadi salah satu faktor pembatas dalam peningkatan produktivitas tanaman. Upaya untuk mengatasi permasalahan tersebut pada tanah masam, diantaranya dilakukan dengan penggunaan FMA dan pupuk organik.

FMA menginfeksi sistem perakaran tanaman inang dengan membentukjalinan hifa secara intensif, sehingga 
tanaman mampu meningkatkan penyerapan hara dan air. Peningkatan tersebut tidak hanya terhadap unsur hara makro tetapi juga unsur mikro, namun yang lebih utama adalah unsur hara fosfat, karena infeksi mikoriza pada tanaman dapat menghasilkan enzim fosfatase yang dapat berfungsi meningkatkan ketersediaan fosfat tanah yang sebenarnya tidak tersedia (Beinroth, 2001). Sedangkan pupuk organik memiliki kandungan hara yang lengkap, bahkan juga terdapat senyawa organik lain yang bermanfaat bagi tanaman, seperti asam humik, asam fulfat dan senyawa-senyawa organik lainnya namun kandungannya rendah (Sumarsono et al., 2005). Pupuk organik dapat memperbaiki struktur tanah dan membantu perkembangan mikroorganisme tanah, ini sebagai awal proses transfomasi $\mathrm{N}$ secara biologis dalam tanah, dan menghasilkan konversi bentuk $\mathrm{N}$ organik menjadi bentuk anorganik yang tersedia bagi tanaman (Widjayanto et al., 2001).

Berdasarkan kerangka pemikiran diatas, dengan dugaan adanya hubungan antara FMA dan pupuk organik, maka penelitian dengan menggabungkan kedua faktor tersebut perlu dilakukan yang diarahkan pada peningkatan hasil dan nilai nutrisi rumput kumpai (Hymenachne amplexicaulis (Rudge) Nees.) di tanah masam podzolik merah kuning. Tujuan penelitian ini adalah untuk mempelajari dan mengetahui pengaruh FMA dan pupuk organik serta interaksinya terhadap peningkatan hasil dan nilai nutrisi rumput kumpai di tanah masam podzolik merah kuning.

\section{MATERI DAN METODE}

\section{Materi Penelitian}

Tempat penelitian di Kelurahan Bagan Pete Kecamatan Kota Baru Kota Jambi, Laboratorium Nutrisi dan Makanan Ternak Fakultas Peternakan Universitas Jambi, Lab. Ilmu Tanah Fak. Pertanian Universitas Andalas, Lab. Biologi Tanaman Universitas Andalas, Lab. Nutrisi Ruminansia, dan Lab. Nutrisi Non Ruminansia Fakultas Peternakan Universitas Andalas. Penelitian berlangsung selama lima bulan, dimulai bulan Februari dan berakhir Juni 2014.

Bahan penelitian yang digunakan adalah rumput kumpai (Hymenachne amplexicaulis (Rudge) Nees.). Rumput ini berasal dari daerah Talang Duku Kabupaten Muaro Jambi Provinsi Jambi. FMA yang digunakan adalah jenis multipel spora dengan merk dagang Cemiko I yang terdiri dari (Glomus sp, Akoulus sp dan Skutelo sp,) diperoleh dari Lab.Tanah Fak. Pertanian Iniversitas Andalas. Pupuk organik yang digunakan adalah pupuk kandang (pukan) kotoran sapi dan pupuk kompos (pukom). Sebagai pupuk dasar digunakan TSP (150 kg $\mathrm{P}_{2} \mathrm{O}_{5} / \mathrm{ha}$ ); $\mathrm{KCl}$ (100 $\mathrm{kg} \mathrm{K} 2 \mathrm{O} / \mathrm{ha}$ ); $\mathrm{CO}\left(\mathrm{NH}_{2}\right)_{2}$ sebanyak $200 \mathrm{~kg} \mathrm{~N} / \mathrm{ha}$; dan $\mathrm{CaCO}_{3}$ (2 ton/ha). Media tanam digunakan tanah masam podzolik merah kuning. Peralatan yang digunakan adalah peralatan pengolah tanah, mistar, alat penyiram, kantong plastik, timbangan, polybag berukuran $10 \mathrm{~kg}$, dan peralatan laboratorium untuk analisa nilai nutrisi hijauan.

\section{Metode Penelitian}

Metode yang dipakai dalam penelitian ini adalah metode eksperimen menggunakan rancangan acak lengkap (RAL) pola faktorial $5 \times 3$, dua faktor sebagai perlakuan yaitu FMA dan pupuk organik. FMA (o g/pot, $10 \mathrm{~g} /$ pot, dan $20 \mathrm{~g} /$ pot); Pupuk organik (o\%, $50 \%$ pukan, $100 \%$ pukan, $50 \%$ pukom dan $100 \%$ pukom). Dengan demikian terdapat 15 kombinasi perlakuan, diulang tiga kali, sehingga terdapat 45 satuan percobaan yang masing-masing terdiri dari dua pot, sehingga jumlah keseluruhannya adalah 90 pot. Peubah yang diamati adalah panjang daun, lebar daun, panjang tanaman, jumlah anakan, jumlah daun, hasil bahan kering hijauan, berat kering akar, protein kasar, kandungan fosfor, kecernaan bahan kering dan kecernaan bahan organic in-vitro.

\section{Pelaksanaan Penelitian}

Sebelum rumput ditanam terlebih dahulu dilakukan pengambilan tanah untuk media tanam secara komposit dari kedalaman 0-20 cm, dibersihkan dari batuan, sisa perakaran dan kerikil sebelum dikeringudarakan. Media tanam dari setiap percobaan ditempatkan dalam pot dengan bobot tanah $7 \mathrm{~kg}$ bobot kering udara. Pupuk dasar TSP, $\mathrm{KCl}, \mathrm{CO}\left(\mathrm{NH}_{2}\right)_{2}$, dan $\mathrm{CaCO}_{3}$ serta pupuk organik sebagai perlakuan diberikan secara bersamaan, dengan cara dicampur dengan tanah dalam pot, kemudian diaduk agar lebih homogen. Inokulum FMA diberikan dengan cara memasukkan inokulum ke dalam setiap lubang tanam, dilakukan bersamaan dengan penanaman rumput. Bahan tanam rumput berupa potongan batang (stek) yang terdiri dari 3 stek/pot. Pemeliharaan yang dilakukan adalah penyiraman dengan air, pengendalian gulma, hama dan penyakit. Pengamatan dilakukan setiap delapan hari. Hasil bahan kering hijauan, berat kering akar, protein kasar, fosfor, kecernaan bahan kering dan kecernaan bahan organik diamati setelah tanaman dipotong. Pemotongan dilakukan sebanyak dua kali dengan interval pemotongan 40 hari. Pengolahan data dilakukan secara statistik dengan rancangan acak lengkap, Analisis ragam dipergunakan untuk mengetahui pengaruh perlakuan dan interaksinya, apabila berpengaruh nyata dilanjutkan dengan uji jarak berganda Duncan.

\section{HASIL DAN PEMBAHASAN}

Hasil analisis ragam menunjukkan bahwa perlakuan FMA dan pupuk organik berpengaruh sangat nyata terhadap semua peubah yang diamati, sedangkan interaksi FMA dan pupuk organik berpengaruh sangat nyata terhadap protein kasar, fosfor dan kecernaan bahan organik. Nilai rataan hasil pengamatan untuk setiap peubah dicantumkan pada Tabel 1, 2 dan 3 di bawah ini.

Pada pemotongan pertama dan kedua perlakuan FMA $20 \mathrm{~g} /$ pot menghasilkan panjang daun dan lebar daun yang lebih tinggi $(\mathrm{P}>0,05)$ dibanding $10 \mathrm{~g} / \mathrm{pot}$ dan berbeda nyata dibanding o g/pot. Selanjutnya 
Tabel 1. Pengaruh FMA dan pupuk organik terhadap panjang daun, lebar daun, panjang tanaman, jumlah anakan, jumlah daun, berat kering hijauan dan berat kering akar rumput kumpai

\begin{tabular}{|c|c|c|c|c|c|c|c|}
\hline Perlakuan & $\begin{array}{l}\text { P.Daun } \\
(\mathrm{cm})\end{array}$ & $\begin{array}{l}\text { L.Daun } \\
(\mathrm{cm})\end{array}$ & $\begin{array}{l}\text { P.Tan. } \\
(\mathrm{cm})\end{array}$ & $\begin{array}{c}\text { J.Anakan } \\
\text { (ank) }\end{array}$ & $\begin{array}{l}\text { J.Daun } \\
\text { (daun) }\end{array}$ & $\begin{array}{l}\text { B.K.Hij } \\
\text { (g) }\end{array}$ & $\begin{array}{c}\text { B.K.Aka } \\
(\mathrm{g})\end{array}$ \\
\hline \multicolumn{8}{|l|}{ Pemotongan I } \\
\hline \multicolumn{8}{|l|}{ FMA: } \\
\hline $0 \mathrm{~g} / \mathrm{pot}$ & 25,59 a & 1,63 a & 80,30 a & 23,20 a & 80,65 a & 58,37 a & \\
\hline $10 \mathrm{~g} / \mathrm{pot}$ & $28,22 \mathrm{~b}$ & $1,78 \mathrm{~b}$ & $91,50 \mathrm{~b}$ & $35,80 \mathrm{~b}$ & $89,70 \mathrm{~b}$ & $72,40 \mathrm{~b}$ & \\
\hline $20 \mathrm{~g} / \mathrm{pot}$ & $29,80 \mathrm{~b}$ & $1,80 \mathrm{~b}$ & $98,25 \mathrm{c}$ & $42,50 \mathrm{c}$ & $95,50 \mathrm{c}$ & $82,20 \mathrm{c}$ & \\
\hline \multicolumn{8}{|l|}{ Pupuk Organik : } \\
\hline Kontrol : $0 \%$ & 25,11 a & $1,30 \mathrm{a}$ & 65,24 a & $22,90 \mathrm{a}$ & $77,50 \mathrm{a}$ & 47,57 a & \\
\hline Pukan : $50 \%$ & $27,60 \mathrm{~b}$ & $1,50 \mathrm{~b}$ & $74,25 \mathrm{c}$ & $28,20 \mathrm{c}$ & $85,50 \mathrm{~b}$ & $67,75 \mathrm{c}$ & \\
\hline Pukan : $100 \%$ & $29,45 c$ & $1,75 \mathrm{c}$ & 86,55 e & $38,50 \mathrm{e}$ & $98,24 \mathrm{c}$ & 75,55 e & \\
\hline Pukom : $50 \%$ & $26,50 \mathrm{~b}$ & $1,45 b$ & $71,20 \mathrm{~b}$ & $25,72 b$ & $84,10 \mathrm{~b}$ & $60,80 \mathrm{~b}$ & \\
\hline Pukom : $100 \%$ & $29,20 \mathrm{c}$ & $1,70 \mathrm{c}$ & $78,80 \mathrm{~d}$ & $32,61 \mathrm{~d}$ & $97,20 \mathrm{c}$ & $70,50 \mathrm{~d}$ & \\
\hline \multicolumn{8}{|l|}{ Pemotongan II } \\
\hline \multicolumn{8}{|l|}{ FMA: } \\
\hline $0 \mathrm{~g} /$ pot & 26,65 a & $1,68 \mathrm{a}$ & 83,40 a & $25,40 \mathrm{a}$ & $85,50 \mathrm{a}$ & 60,48 a & $25,87 \mathrm{a}$ \\
\hline $10 \mathrm{~g} / \mathrm{pot}$ & $29,40 \mathrm{~b}$ & $1,84 \mathrm{~b}$ & $95,20 \mathrm{~b}$ & $40,25 \mathrm{~b}$ & $98,50 \mathrm{~b}$ & $80,45 \mathrm{~b}$ & $27,76 b$ \\
\hline $20 \mathrm{~g} /$ pot & $31,40 \mathrm{~b}$ & $1,90 \mathrm{~b}$ & $105,20 \mathrm{c}$ & $50,30 \mathrm{c}$ & $110,40 \mathrm{c}$ & $88,50 \mathrm{c}$ & $32,20 c$ \\
\hline \multicolumn{8}{|l|}{ Pupuk Organik : } \\
\hline Kontrol : $0 \%$ & 25,35 a & $1,40 \mathrm{a}$ & 85,50 a & $28,11 \mathrm{a}$ & 78,75 a & 50,30 a & $23,36 a$ \\
\hline Pukan : $50 \%$ & $27,75 b$ & $1,70 \mathrm{~b}$ & $93,50 \mathrm{c}$ & $37,60 \mathrm{c}$ & $93,40 \mathrm{~b}$ & $73,80 \mathrm{c}$ & $26,30 \mathrm{c}$ \\
\hline Pukan : $100 \%$ & $30,45 \mathrm{c}$ & $1,85 \mathrm{c}$ & $99,50 \mathrm{e}$ & $42,50 \mathrm{e}$ & $99,70 \mathrm{c}$ & 80,75 e & $30,40 \mathrm{e}$ \\
\hline Pukom : $50 \%$ & $27,30 \mathrm{~b}$ & $1,65 \mathrm{~b}$ & $90,75 \mathrm{~b}$ & $34,40 \mathrm{~b}$ & $91,60 \mathrm{~b}$ & $68,05 \mathrm{~b}$ & $24,01 b$ \\
\hline Pukom : $100 \%$ & $29,20 \mathrm{c}$ & $1,80 \mathrm{c}$ & $96,40 \mathrm{~d}$ & $38,40 \mathrm{~d}$ & $97,20 \mathrm{c}$ & $77,56 \mathrm{~d}$ & $28,76 \mathrm{~d}$ \\
\hline
\end{tabular}

Keterangan : Nilai rataan yang diikuti oleh huruf kecil berbeda pada kolom yang sama menunjukkan berbeda nyata pada taraf $5 \%$ berdasarkan uji jarak berganda Duncan.

FMA $10 \mathrm{~g} /$ pot hasilnya lebih tinggi $(\mathrm{P}<0,05)$ dibanding o g/pot. Sedangkan panjang tanaman, jumlah anakan, jumlah daun dan hasil bahan kering hijauan pada FMA $20 \mathrm{~g} /$ pot juga menunjukkan hasil tertinggi $(\mathrm{P}<0,05)$ dibanding $10 \mathrm{~g} /$ pot dan $\mathrm{og} /$ pot, demikian juga FMA $10 \mathrm{~g} /$ pot dibanding $\mathrm{o}$ g/pot.

Perlakuan FMA $10 \mathrm{~g} /$ pot pada pemotongan pertama dan kedua dapat meningkatkan panjang daun (10,28\% dan 10,32\%), lebar daun (9,20\% dan 9,50\%), panjang tanaman (13,95\% dan 14,15\%), jumlah anakan $(54,31 \%$ dan $58,47 \%)$, jumlah daun $(11,22 \%$ dan $15,12 \%)$ serta hasil bahan kering hijauan (24,04\% dan 33,02\%), sedangkan pada FMA $20 \mathrm{~g} /$ pot terjadi peningkatan panjang daun (16,45\% dan 17,82\%), lebar daun (10,43\% dan $13,10 \%)$, panjang tanaman (22,35\% dan $26,14 \%)$, jumlah anakan (83,15\% dan 98,03\%), jumlah daun $(18,41 \%$ dan $29,12 \%)$ serta hasil bahan kering hijauan (40,83\% dan 46,33\%) dibanding FMA o g/pot.

Secara keseluruhan dapat dikemukakan bahwa lebih tingginya hasil pada perlakuan FMA, disebabkan karena FMA dapat memperbaiki struktur tanah dan meningkatkan absorpsi hara dari tanah, dengan meningkatnya serapan hara, maka fotosintesis akan meningkat sehingga makin banyak karbohidrat yang dihasilkan oleh tanaman yang akan digunakan untuk pembentukan bagian-bagian vegetatif tanaman. Beinroth (2001) menyatakan bahwa FMA dapat meningkatkan penyerapan unsur hara dan air dari dalam tanah, yang akan memungkinkan tanaman menghasilkan sel-sel baru dan hormonhormon pertumbuhan yang kemudian akan mampu meningkatkan pertumbuhan bagian vegetatif tanaman. Menurut Husin (2012), hifa (miselium) FMA dapat meningkatkan nutrisi tanaman dan menghasilkan hormon pertumbuhan seperti auksin dan giberelin. Auksin berfungsi mencegah penuaan akar, sehingga berfungsi lebih lama dalam penyerapan unsur hara lebih banyak, sedangkan giberelin berfungsi untuk merangsang pembesaran dan pembelahan sel terutama sel primer. Hasil penelitian Kanno et al. (2006) pemberian FMA dapat meningkatkan pertumbuhan dan produksi hijauan makanan ternak tropika. Karti (2004) pemberian FMA dapat meningkatkan pertumbuhan dan produksi rumput Setaria splendida Stapf yang mengalami cekaman kekeringan. Nania (2007) pemberian CMA pada tanah salin dapat meningkatkan pertumbuhan dan produksi rumput Chloris gayana Kunt, hasil terbaik diperoleh pada pemberian mikoriza $20 \mathrm{~g} /$ pot dan pupuk NPK 840 $\mathrm{kg} / \mathrm{ha}$. Hasil penelitian Karti dan Setiadi (2011) pemberian FMA mampu meningkatkan pertumbuhan dan produksi rumput Chloris gayana pada tanah masam dengan aluminium tinggi.

Perlakuan pukan 100\% menghasilkan panjang daun, lebar daun dan jumlah daun tertinggi $(\mathrm{P}>0,05)$ dibanding pukom $100 \%$, berbeda nyata dibanding pukom 50\%, pukan 50\% dan 0\%; pukom 100\% hasilnya lebih tinggi $(\mathrm{P}<0,05)$ dibanding pukom $50 \%$, pukan 50\% dan 0\%; pukom 50\% hasilnya lebih tinggi $(\mathrm{P}>0,05)$ dibanding pukan $50 \%$ dan berbeda nyata dibanding 0\%. Selanjutnya perlakuan pukan 100\% menghasilkan panjang tanaman, jumlah anakan, berat kering akar dan hasil bahan kering hijauan tertinggi $(\mathrm{P}<0,05)$ dibanding pukom $100 \%$, pukan $50 \%$, pukom 50\% dan 0\%; pukom 100\% hasilnya lebih tinggi $(\mathrm{P}<0,05)$ dibanding pukan $50 \%$, pukom $50 \%$ dan $0 \%$; demikian juga dengan pukan $50 \%$ dibanding pukom $50 \%$ dan $0 \%$, serta pukom $50 \%$ dibanding $0 \%$. 
Peningkatan hasil bahan kering hijauan tertinggi pada pemotongan pertama dan kedua diperoleh dari perlakuan pukan $100 \%(58,82 \%$ dan $60,54 \%)$, diikuti pukom $100 \%$ ( $48,20 \%$ dan $54,20 \%)$, pukan $50 \%$ (42,42\% dan 46,72\%), pukom 50\% (27,81\% dan $35,29 \%$ ) dibanding $0 \%$. Dengan pemberian pupuk organik dapat menghasilkan bahan kering hijauan yang lebih tinggi dibanding tanpa pupuk organik, peningkatan hasil bahan kering hijauannya selaras dengan penambahan taraf dosis pupuk organik. Karena semakin meningkat taraf pemberian pupuk organik, akan meningkatkan kandungan unsur hara, perbaikan sifat fisik, kimia, biologis tanah, dapat menjaga dan meningkatkan kesuburan tanah, sehingga produktivitas tanaman menjadi meningkat. Hardjowigeno (2003) menyatakan bahwa penambahan bahan organik ke dalam tanah mempunyai fungsi, antara lain sebagai sumber unsur hara, pengikat unsurunsur mikro dan kation, meningkatkan kapasitas tukar kation, $\mathrm{pH}, \mathrm{C}$ organik dan meningkatkan ketersediaan fosfor. Irwan et al. (2004) menyatakan bahwa pemberian pupuk organik kotoran sapi mampu meningkatkan pertumbuhan dan produksi tanaman sorghum (Sorghum bicolor (Linn) Moench.) pada tanah inseptisol. Sandrawati et al. (2007) penambahan pupuk kandang sapi dan kompos memberikan pengaruh positif terhadap peningkatan produktivitas tanaman jagung di tanah Fluventic Eutrudepts.

Pada Tabel 2 perlakuan FMA 20 g/pot menghasilkan protein kasar, fosfor, kecernaan bahan kering dan kecernaan bahan organik tertinggi $(\mathrm{P}<0,05)$ dibanding $10 \mathrm{~g} /$ pot dan $\mathrm{o}$ g/pot, selanjutnya FMA $10 \mathrm{~g} /$ pot hasilnya lebih tinggi $(\mathrm{P}<0,05)$ dibanding $\mathrm{o} g /$ pot. Sedangkan untuk pupuk organik, perlakuan pukan 100\% menghasilkan protein kasar, fosfor, kecernaan bahan kering dan kecernaan bahan organik tertinggi $(\mathrm{P}<0,05)$ dibanding pukom $100 \%$, pukan $50 \%$, pukom 50\% dan o\%; pukom 100\% hasilnya lebih tinggi ( $\mathrm{P}<0,05)$ dibanding pukan 50\%, pukom 50\% dan 0\%; pukan $50 \%$ lebih tinggi $(\mathrm{P}<0,05)$ dibanding pukom $50 \%$ dan o\%; dan pukom $50 \%$ lebih tinggi $(\mathrm{P}<0,05)$ dibanding $0 \%$.

Perlakuan FMA $10 \mathrm{~g} /$ pot dan $20 \mathrm{~g} /$ pot dapat meningkatkan protein kasar $(24,81 \%$ dan $33,59 \%)$, fosfor $(41,18 \%$ dan $88,24 \%)$, kecernaan bahan kering $(28,00 \%$ dan $36,41 \%)$ serta kecernaan bahan organik (29,98\% dan 36,26\%) dibanding FMA o g/ pot. Selanjutnya pada perlakuan FMA $20 \mathrm{~g}$ /pot dapat meningkatkan protein kasar (7,03\%), fosfor (33,33\%), kecernaan bahan kering $(6,57 \%)$ dan kecernaan bahan organik $(4,83 \%)$ jika dibandingkan dengan FMA 10 g/pot.

Meningkatnya nilai nutrisi rumput kumpai pada perlakuan FMA, disebabkan karena hifa dari FMA yang berasosiasi dengan akar, menyebabkan tanaman mampu menyerap unsur hara dalam tanah lebih banyak, dapat menyerap air dari pori-pori tanah pada saat tanaman tidak mampu lagi menyerap air, karena penyerapan air oleh hifa dalam tanah sangat luas sehingga tanaman dapat memperoleh air lebih banyak.
Tabel 2. Pengaruh FMA dan pupuk organik terhadap protein kasar, fosfor, kecernaan bahan kering dan kecernaan bahan organik rumput kumpai.

\begin{tabular}{ccccc}
\hline Perlakuan & $\begin{array}{c}\text { Prot. Kasar } \\
(\%)\end{array}$ & $\begin{array}{c}\text { Kand. P } \\
(\%)\end{array}$ & $\begin{array}{c}\text { KCBK } \\
(\%)\end{array}$ & $\begin{array}{c}\text { KCBO } \\
(\%)\end{array}$ \\
\hline FMA: & & & & \\
0 g/pot & $13,10 \mathrm{a}$ & $0,85 \mathrm{a}$ & $48,75 \mathrm{a}$ & $50,20 \mathrm{a}$ \\
$10 \mathrm{~g} /$ pot & $16,35 \mathrm{~b}$ & $1,20 \mathrm{~b}$ & $62,40 \mathrm{~b}$ & $65,25 \mathrm{~b}$ \\
20 g/pot & $17,50 \mathrm{c}$ & $1,60 \mathrm{c}$ & $66,50 \mathrm{c}$ & $68,40 \mathrm{c}$ \\
Pupuk Organik : & & & & \\
Kontrol : $0 \%$ & $13,25 \mathrm{a}$ & $0,65 \mathrm{a}$ & $50,10 \mathrm{a}$ & $52,15 \mathrm{a}$ \\
Pukan : $50 \%$ & $15,60 \mathrm{c}$ & $0,97 \mathrm{c}$ & $61,63 \mathrm{c}$ & $63,75 \mathrm{c}$ \\
Pukan : $100 \%$ & $17,15 \mathrm{e}$ & $1,25 \mathrm{e}$ & $66,90 \mathrm{e}$ & $68,20 \mathrm{e}$ \\
Pukom : $50 \%$ & $14,45 \mathrm{~b}$ & $0,78 \mathrm{~b}$ & $57,50 \mathrm{~b}$ & $60,20 \mathrm{~b}$ \\
Pukom : $100 \%$ & $16,15 \mathrm{~d}$ & $1,18 \mathrm{~d}$ & $64,26 \mathrm{~d}$ & $65,85 \mathrm{~d}$ \\
\hline
\end{tabular}

Keterangan : Nilai rataan yang diikuti oleh huruf kecil berbeda pada kolom yang sama menunjukkan perbedaan nyata pada taraf $5 \%$ berdasarkan uji jarak berganda Duncan.

Hal ini dapat terlihat dengan baiknya perkembangan sistem perakaran yang dicerminkan oleh tingginya berat kering akar pada tanaman yang mendapat perlakuan FMA (Tabel 1.). Terjadi sistem simbiosis mutualisme karena fungi mikoriza yang hidup di dalam sel akar mendapat sebagian karbon dari hasil proses fotosintesis tanaman, dan tanaman akan mendapatkan hara ataupun keuntungan lainnya dari fungi mikoriza. Menurut Husin (2012), hifa (miselium) FMA dapat meningkatkan nilai nutrisi tanaman dan menghasilkan hormon tumbuh auksin dan giberelin. FMA berfungsi untuk meningkatkan absorpsi hara dari dalam tanah, tanaman yang bermikoriza umumnya tumbuh lebih baik daripada tanpa mikoriza (Tabel 1.), dan secara efektif dapat meningkatkan penyerapan unsur hara diantaranya $\mathrm{N}, \mathrm{P}, \mathrm{K}$ dan $\mathrm{Mg}$, dengan meningkatnya penyerapan unsur hara akan berdampak positif terhadap pertumbuhan bagian-bagian vegetatif dan nilai nutrisi hijauan.

Pada perlakuan pupuk organik, peningkatan nilai nutrisi hijauan tertinggi diperoleh pada pukan $100 \%$, yakni protein kasar (29,43\%), fosfor $(92,30 \%)$, kecernaan bahan kering (33,53\%) dan kecernaan bahan organik (30,78\%); diikuti pukom $100 \%$, yakni protein kasar (21,89\%), fosfor (81,5\%), kecernaan bahan kering (28,26\%) dan kecernaan bahan organik $(26,27 \%)$; selanjutnya pukan $50 \%$, protein kasar $(17,74 \%)$, fosfor $(49,23 \%)$, kecernaan bahan kering $(23,01 \%)$ dan kecernaan bahan organik (22,24\%); serta pukom $50 \%$ protein kasar $(9,06 \%)$, fosfor $(1,54 \%)$, kecernaan bahan kering $(14,77 \%)$ dan kecernaan bahan organik $(15,44 \%)$ dibanding tanpa pupuk organik. Secara keseluruhan dapat dikemukakan bahwa pemberian pupuk organik menghasilkan nilai nutrisi hijauan yang lebih tinggi dibanding tanpa pupuk organik, peningkatannya selaras dengan penambahan taraf dosis pupuk organik. Simanungkalit et al. (2006) menyatakan bahwa pupuk organik atau bahan organik tanah merupakan sumber nitrogen tanah yang utama, selain itu peranannya cukup besar terhadap perbaikan sifat fisik, kimia dan biologis tanah serta lingkungan. Pupuk organik yang ditambahkan ke dalam tanah akan mengalami beberapa kali fase perombakan oleh 
Tabel 3. Pengaruh interaksi FMA dan pupuk organik terhadap protein kasar, fosfor dan kecernaan bahan organik rumput kumpai

\begin{tabular}{|c|c|c|c|c|}
\hline \multicolumn{2}{|c|}{ Perlakuan } & $\begin{array}{c}\text { Prot. Kasar. } \\
(\%)\end{array}$ & $\begin{array}{c}\text { Kand.Fosfor } \\
(\%)\end{array}$ & $\begin{array}{c}\text { Kec. Bahan Organik } \\
(\%)\end{array}$ \\
\hline \multirow[t]{3}{*}{ FMA: } & Pupuk Organik: & & & \\
\hline & $0 \%$ & $12,23 \mathrm{e}$ & $0,50 \mathrm{~h}$ & $57,10 \mathrm{e}$ \\
\hline & 50 \% pukan & $13,25 d$ & $0,73 \mathrm{f}$ & $60,02 \mathrm{~d}$ \\
\hline \multirow[t]{5}{*}{$0 \mathrm{~g} / \mathrm{pot}$} & 100 \% pukan & $14,55 \mathrm{c}$ & 0,87 de & $64,95 \mathrm{~b}$ \\
\hline & $50 \%$ kompos & $13,10 \mathrm{~d}$ & $0,67 d$ & $58,70 \mathrm{~d}$ \\
\hline & $100 \%$ kompos & $14,30 \mathrm{c}$ & $0,80 \mathrm{c}$ & $63,73 b$ \\
\hline & $0 \%$ & $13,74 \mathrm{~cd}$ & $0,57 \mathrm{~h}$ & $61,20 \mathrm{c}$ \\
\hline & 50 \% pukan & $15,13 \mathrm{~b}$ & $1,25 \mathrm{bc}$ & $62,21 \mathrm{c}$ \\
\hline \multirow[t]{5}{*}{$10 \mathrm{~g} / \mathrm{pot}$} & $100 \%$ pukan & $16,36 \mathrm{a}$ & 1,47 a & $68,26 a$ \\
\hline & $50 \%$ kompos & 14,72 bc & $0,81 \mathrm{~d}$ & $61,84 \mathrm{~d}$ \\
\hline & $100 \%$ kompos & $15,85 \mathrm{ab}$ & $1,42 \mathrm{a}$ & $67,81 \mathrm{ab}$ \\
\hline & $0 \%$ & $14,23 \mathrm{c}$ & $0,62 \mathrm{f}$ & $61,35 \mathrm{~d}$ \\
\hline & 50 \% pukan & 15,47 & b 1,30 b & $65,31 \mathrm{~b}$ \\
\hline \multirow[t]{3}{*}{$20 \mathrm{~g} / \mathrm{pot}$} & $100 \%$ pukan & $17,13 \mathrm{a}$ & 1,49 a & 69,56 a \\
\hline & 50 \% kompos & $15,10 \mathrm{~b}$ & $0,85 \mathrm{c}$ & $62,40 \mathrm{c}$ \\
\hline & $100 \%$ kompos & 16,38 a & $1,45 \mathrm{a}$ & 68,96 a \\
\hline
\end{tabular}

mikroorganisme tanah untuk menjadi humus atau bahan organik tanah. Sehingga sangat bermanfaat bagi peningkatan produktivitas tanaman baik kuantitas maupun kualitas.

Pengaruh interaksi FMA dan pupuk organik terhadap protein kasar, fosfor dan kecernaan bahan organik, menunjukkan bahwa kombinasi perlakuan FMA $20 \mathrm{~g} /$ pot dengan pukan 100\% menghasilkan protein kasar, fosfor dan kecernaan bahan organik tertinggi walaupun tidak berbeda nyata dibanding FMA $20 \mathrm{~g} /$ pot dengan pukom 100\%, FMA $10 \mathrm{~g} / \mathrm{pot}$ dengan pukan $100 \%$ serta FMA $10 \mathrm{~g} /$ pot dengan pukom $100 \%$, tetapi berbeda nyata dibandingkan dengan kombinasi perlakuan lainnya (Tabel 3).

Secara keseluruhan dapat dikemukakan bahwa peningkatan kandungan protein kasar, fosfor dan kecernaan bahan organik tertinggi diperoleh dengan pemberian FMA. Hal ini disebabkan karena FMA dapat menginfeksi sistem perakaran tanaman inang dengan membentuk jalinan hifa secara intensif, yang menyebabkan tanaman mampu meningkatkan penyerapan hara, air, dan yang lebih utama unsur hara fosfat, karena ketersedian fosfat pada tanah masam merupakan salah satu faktor pembatas dalam peningkatan produktivitas tanaman (Husin et al., 2012). Menurut Beinroth (2001) bahwa infeksi mikoriza pada tanaman dapat menghasilkan enzim fosfatase yang dapat berfungsi meningkatkan ketersediaan fosfat yang rendah ketersediaannya pada tanah masam. Selain itu FMA juga berfungsi untuk memperbaiki struktur tanah yang memungkinkan perakaran tanaman berkembang dan berfungsi dengan baik, kondisi ini menyebabkan lebih banyak unsur hara dapat diserap oleh tanaman, dan fotosintesis menjadi meningkat akan menghasilkan lebih banyak karbohidrat untuk pembentukan dan perkembangan bagian-bagian vegetatif tanaman, sehingga akhirnya juga akan memberikan hasil yang baik terhadap nilai nutrisi hijauan.

Pupuk organik sebagai sumber bahan organik sangat diperlukan untuk perkembangan mikoriza, karena FMA sebagai biofertilizer membutuhkan kondisi lingkungan yang sesuai untuk mengoptimalkan perkembangannya. Utomo (1995) dalam Nania (2007) menyatakan bahwa disamping $\mathrm{pH}$ tanah, kondisi tanah yang mempengaruhi perkembangan mikoriza diantaranya adalah ketersediaan bahan organik dan ketersediaan hara. Oleh sebab itu pada kondisi penelitian ini, dapat dikemukakan bahwa dengan semakin meningkatnya pemberian FMA dan pupuk organik, akan memberikan peningkatan terhadap kandungan proten kasar, fosfor dan kecernaan bahan organik hijauan. Disamping itu pemberian pupuk organik dapat membantu perkembangan mikroorganisme tanah, ini adalah sebagai awal proses transfomasi $\mathrm{N}$ secara biologis dalam tanah, dan menghasilkan konversi bentuk $\mathrm{N}$ organik menjadi bentuk anorganik yang tersedia bagi tanaman (Widjayanto dkk., 2001), sehingga memberikan hasil yang baik terhadap nilai nutrisi rumput kumpai.

\section{SIMPULAN}

1. Perlakuan FMA dan pupuk organik berpengaruh nyata terhadap semua peubah yang diamati, sedangkan interaksi FMA dan pupuk organik berpengaruh sangat nyata terhadap kandungan protein kasar, fosfor dan kecernaan bahan kering rumput kumpai.

2. Hasil bahan kering dan nilai nutrisi rumput kumpai tertinggi diperoleh pada perlakuan FMA $20 \mathrm{~g} /$ pot, sedangkan untuk pupuk organik diperoleh pada perlakuan pukan $100 \%$.

3. Kombinasi perlakuan FMA $20 \mathrm{~g} /$ pot dengan pukan $100 \%$ menghasilkan protein kasar, fosfor dan kecernaan bahan organik tertinggi walaupun tidak berbeda dibanding FMA $20 \mathrm{~g}$ /pot dengan pukom $100 \%$, FMA $10 \mathrm{~g} /$ pot dengan pukan 100\% serta FMA $10 \mathrm{~g}$ /pot dengan pukom 100\%, tetapi berbeda dibandingkan dengan kombinasi perlakuan lainnya.

4. Hasil bahan kering dan nilai nutrisi rumput kumpai meningkat selaras dengan peningkatan taraf dosis FMA maupun pupuk organik.

\section{DAFTAR PUSTAKA}

Mulyani, A. dan I. Las. 2008. Potensi Sumber Daya Lahan dan Optimalisasi Pengembangan Komoditas Penghasil Bioenergi di Indonesia.

Sandrawati, A., E. T.Sofyan dan O. Mulyani. 2007. Pengaruh Kompos Sampah Kota dan Pupuk Kandang Sapi terhadap Sifat Kimia Tanah dan Hasil Tanaman Jagung Manis (Zea mays saccharata) pada Fluventic Eutrudepts Asal Jatinangor Kabupaten Sumedang.

Beinroth, F.H. 2001. Land Resources for Forage Production in the Tropics In Sotomayor - Rios A. Pitman Wd (eds) Tropical Forage Plants Development and Use CRC Press. 
Pp3-15.

Dinas Pertanian Tanaman Pangan Provinsi Jambi. 2005. Pengembangan Tanaman Pangan di Jambi. Jambi.

Zuhry, E. dan F. Puspita. 2008. Pemberian Cendawan Mikoriza Arbuskula Pada Tanah Podzolik Merah Kuning Terhadap Pertumbuhan dan Produksi Kedelai (Glycine max (L) Merill). Majalah Ilmiah SAGU, Vol. 7. No: 2:25-29. ISSN: 1412-4414.

Evitayani, A. Fariani, L. Warly, Suyitman, S. Yani dan Emikasmira. 2012. Pengaruh Dosis Pupuk N, P, dan K terhadap KecernaanSecara In Vitro Rumput Gajah (Pennisetum purpureum) cv. Taiwan yang di Inokulasi CMA Glomus manihotispada Lahan Bekas Tambang Batubara. Jurnal Peternakan Indonesia. Vol.14 (I) : $279-285$.

Husin, E. F., A. Syarif dan Kasli. 2012. Mikoriza sebagai Pendukung Sistem Pertanian Berkelanjutan dan Berwawasan Lingkungan. Andalas University Press.

Hardjowigeno, S. 2003. Ilmu Tanah. Edisi Baru. Akademika Pressindo. Jakarta.

Irwan, A.W., A.Wahyudin, R.Susilawati dan T. Nurmala. 2005. Interaksi Jarak Tanam dan Jenis Pupuk Kandang terhadap Komponen Hasil dan Kadar Tepung sorghum (Sorghum bicolor (Linn.) Moench.) pada Inseptisol di Jatinamgor.

Jamarun, N. dan M. Zain. 2012. Dasar Nutrisi Ruminansia. Penerbit Jasa Surya Padang.

Kanno, T., M. Saito, Y.Ando, M. C. M. Macedo, T. Nakamura and C.H.B. Miranda. 2006. Importance of indigenous arbuscular mycorrhizal for growth and phosphourus uptake in tropical forage grasses growing on an acid soil, infertile soil from the Brazilian savannas. Trop. Grasslands. 40:94-101.

Karti, P. D. M. H. 2004. Pengaruh Pemberian Cendawan Mikoriza Arbuskula terhadap Pertumbuhan dan Produksi Rumput Setaria splendida Stapf. yang Mengalami Cekaman Kekeringan. Media Peternakan (27):63-68.
Karti, P.D.M.H dan Y. Setiadi. 2011. Respon Pertumbuhan, Produksi dan Kualitas Rumput terhadap Penambahan Fungi Mikoriza Arbuskula dan Asam Humat pada Tanah Masam dengan Alumunium tinggi. JITV 16(2): 104-111.

Mengel, K., and Kirkby, E. A. 2001. Principles of plant nutrition. $5^{\text {th }}$ ed., Kluwer Academic Publishers, Dordrecht.

Rachim, A . R., Situmorang dan A. Hartono. 2000. Konsep Pengembangan Pertanian Berkelanjutan di Lahan Rawa untuk Mendukung Ketahanan Pangan dan Pengembangan Agribisnis.

Simanungkalit, M.D.R., D.R. Suriadikarta, R. Saraswati, D. Setyorii dan W. Hartatik. 2006. Pupuk Organik dan Pupuk Hayati (Organic Fertilizer and Biofertilizer). Balai Besar Litbang Sumberdaya Lahan Pertanian, Badan Penelitian dan Pengembangan Pertanian Bogor.

Sukarmin dan Fatria, D. 2011. Teknik Inokulasi Fungi Mikoriza Arbuskula pada Benih Sirsak. Bulletin Teknik Pertanian Vol.16, No. 2: $52-54$.

Sumarsono, S. Anwar dan S. Budiyanto. 2005. Peranan Pupuk Organik untuk Keberhasilan Pertumbuhan Tanaman Pakan Rumput Poliploid pada Tanah Masam dan Salin. Laporan Penelitian. Fakultas Peternakan Universitas Diponegoro, Semarang.

Sumarsono. 2006. Peran Tanaman Pakan dalam Intervensi Pertanian Berwawasan Lingkungan. Makalah Utama dalam Silaturahmi Ilmiah Internal Fakultas Peternakan Universitas Diponegoro, Semarang, 29 Maret 2006.

Nania, V. 2007. Penambahan Cendawan Mikoriza Arbuskula dan Pupuk NPK pada Tanah Salin terhadap Pertumbuhan dan Produksi Rumput Chloris gayana Kunth. dan Setaria splendida Stapf. Fakultas Peternakan Institut Pertanian Bogor. 